\title{
A LEGITTIMA DEFESA
}

1 - Conceito. 2 - História. 3 - Sua natureza. jurílica. 4 - Direitos que protege. 5 - Requisitos. 6 - Animo de ataque e ânimo de defesa. 7 - A falto de provocação e o excesso.

\section{Luiz Jimenez de Asua}

\section{1 - CONCEITO:}

Cremos que a legítima defesa era, entre tôdas as causas de justificação a mais característica, a primeira que se desprendeu dêsse amorfo de exceção-regra e que já existia no direito romano, aperfeiçoando-se na Idade Média.

Se quisermos definí-la, diremos que é a repulsa necessária a uma agressão injusta, atual ou iminente, para defender nosso direito ou de outrém, sempre que houver a proporçã்o dos meios e não houver provocação por parte de quem se defende. Este conceito não é o mesmo adotado pelo Código Penal Brasileiro, que dispõe em seu artigo 21: - "ENTENDE-SE EM LEGÍTIMA DEFESA QUEM, USANDO MODERADAMENTE DOS MEIOS NECESSÁRIOS, REPELE INJUSTA AGRESSÃO; ATUAL OU IMINENTE, A DIREITO SEU OU DE OUTREM". Sôbre essa definição que corresponde à base dogmática, e que é a reconstrução do direito vigente em base científica, vamos discorrer. Contudo, não seria demais fazer alusão ao que ocorreu através dos tempos.

\section{2 - HISTÓRIA:}

Quando historiamos o injusto, antes de entrar no processo histórico dogmático, dissemos que em Roma, no direito germânico e na Idade Média salvo alguns práticos geniais, a maior parte das causas de justificação existiam sem distinguir-se das outras e sem diferençar a injustiça do dolo.

Mas houve uma dessas causas, no direito romano, no direito canônico e no direito germânico que foi exatamente a legítima defesa. Os textos romanos eram na verdade contraditórios. Alguns 
falavam de "arma armis" (armas iguais) para que a defesa fôsse completa, isto é, o meio de defesa devia corresponder ao de ataque. Pouco a pouco, porém, a lei foi atenuando essa exigência quanto à qualidade das armas. Foi o direito canônico que criou o princípio de proporção dos meios e exigiu ainda mais que o direito romano; estabelecendo:

\section{"MODERAMEN INCULPATE TUTELAE"}

O direito germânico concebeu um direito de necessidade com uma grande amplitude.

Durante tôda a Idade Média foi a legítima defesa adquirindo características mais prezisas e nas Partidas no século XIII, encontramos a mesma forma atual, admitindo a legaitimidade da defesa contra uma agressão iminente.

No século XVIII a legítima defesa passou a figurar na parte geral, onde continua, não obstante aparecer, ao contrário, no Código Napoleônico (1810), encravada na parte especial junto ao homicídio.

\section{3 - NATUREZA JURÍDICA}

Quanto à natureza da legítima defesa, justamente nessa zona imprecisa em que sstavam as causas de justificação, se deve, a que não se sabia, se excluíam o injusto, odolo ou a imputabilidade.

A locução - IMBECILITAS HUMANA - do latim, quer dizer, debilidade humana, não só se aplica ao estado de necessidade, senão também, como base da legítima defesa, pois não se pode exigir que alguém se sacrifique.

PUFFENDORF fala que a legítima defesa se fundava na perturbação de ânimo do indivíduo ao ser atacado; em suma, do mêdo, e afirmativa“ — PROPTER PERTURBATIONIS ANIMO6'. Em poucas palavras, êsse mêdo é que justificava se repelisse a agressão. Mas essa explicação não só é insuficiente como equívoca. Insufici ente porque a mais elegante forma de legítime defesa é a de terceiro, onde agimos porque estejamos perturbados, pela ação do mêdo, quando defendemos outra pessoa. Não é possível conceber a elgítima defesa como impulsionada pela perturbação, porque, nesse caso, seria causa de inimputabilidade e não de justificação.

Podíamos dizer que é uma falta de dolo?

Todavia, os positivistas italianos, se referiram ao sujeito para exculpá-lo por falta de móvel social na legítima defesa.

Antigamente, no tempo dos Práticos, havia a falta de dolo, para eliminiar a responsabilidade. A posição que hoje se admite é de que, quem age em legítima defesa, se esta é em verdade legítima, realiza uma causa de justificação, isto é, que se legitima intrìnsecamente o fato. A causa de justificação faz desaparecer uma injustiça aparente e deixa claro que a conduta de quem se defende é legítima.

Daí surgem várias conseqüências.

Os positivistas, especialmente FIORETTI, ZERBOGLIO, FLORIAN, FERRI, dizem que a legítima defesa é uma justificação subjetiva. Aplicam êles sua tese de falta de reação do homem com fim anti-social, ou seja, a teoria dos motivos anti-sociais e sociais.

Entretanto, insistimos que a legítima defesa não provêm dos motivos, mas das justificações objetivas. A índole objetiva do injusto faz que seja objetiva a injustiça, e que se a justifique, não é porque creia o agente mas por não ser anti-social o motivo visto estar conforme à norma de cultura.

Assim, um louco pratica atos pelos quais não é responsável mas contra êle cabe a legítima defesa, porque, objetivamente, a conduta do louco é injusta. Contràriamente, não cabe legítima defesa contra os animais por serem incapazes de atos injustos. Se matarmos um cachorro que nos quer morder, há um estado de necessidade, pois a legítima defesa só pode resultar de um ato injusto privativo do ser humano.

Contra um ato justo não é possível uma repulsa justa.

FERRI falou da legítima defesa recíproca, o que, em nosso modo de ver, é impossível. Citou o exemplo do homem que, em sua própria casa, surpreende o noivo da cozinheira, que faz um movimento que supõe ser agressivo, e, diante disso, dispara o seu revólver e recebe em revide um tiro mortal. Afirma FERRI que há aqui uma caso de legítima defesa recíproca. FLAGRANTE ABSURDO. Porque, nesse caso, o dono da casa se encontrava em estado de defesa putativa e o noivo da cozinheira em legítima defesa. Isso porque aquêle que se supõe em legítima defesa, está realmente agindo em defesa putativa, visto como a legítima defesa real é essencialmente objetiva. No caso citado, o noivo da cozinheira, sem agredir, foi agredido. Logo, agiu em legítima defesa. Quanto ao proprietário da casa, supondo-se na eminência de uma agressão, agiu por êrro, portanto em defesa putativa.

A legítima defesa recíproca não é possível porque quem pratica um ato injusto não pode estar em legítima defesa. Vejamos, vai ser executado um condenado à morte. $O$ verdugo vai realizar a execução do prêso que não se pode opor porque não cabe legítima defesa contra um ato lícito.

Dessas conseqüências se deduz que a legítima defeza é considerada, em seu verdadeiro sentido, como causa de justificação. 
Outra conseqüência é a de saber se comportam indenização os atos praticados em legítima defesa. Não, porque os atos justificados não dão lúgar à responsabilidade civil

\section{4 - DIREITOS QUE PROTEGE}

Entraremos, agora, na interpretação técnico-dogmática da legítima defesa e determinaremos os direitos defendíveis.

No Código Penal Brasileiro há duas partes no artigo 21:

a) $\mathrm{O}$ agente pode defender-se a si mesmo;

b) e a outrem,

portanto há dois titulares de defesa.

A defesa de terceiro pode exercer-se tanto pelo parente como por pessoa estranha. ALIMENA afirmava que a defesa de terceior era a mais bela. O certo é que o Código Brasileiro, como o Argentino e o Espanhol, diversamente de outros, entre os quais o Colombiano, não enuncia os direitos defendidos, senão, e tão-sòmente, refere-se ao direito próprio ou de outrem. Mas os intérpretes dizem, com razão, que não estando êstes direitos limitados - (a vida, a integridade corporal, a honra, a propriedade, a liberdade), são todos passíveis de legítima defesa.

Para solucionar o conflito que pode apresentar-se entre a faculdade de defender um direito e a injustiça resultante de um meio exorbitante, nós outros propomos, como logo se verá, o requisito, indeclinável de que a defesa seja necessária.

No caso em que uma pessoa trata de defender sua propriedade ou a de outrem, repelindo a agressão, a hipótese já não se apresenta fácil.

Discutiu-se a respeito dos aparelhos predispostos que eram antigamente usados e muito simples. No Brasil há o uso de muros coroados por pontas de ferro ou cacos de vidros, meios predispostos para evitar a entrada de pessoas estranhas, escalando-os. Esse sistema já era conhecido em Roma com o nome de ofendícula. Atualmente existem aparelhos predispostos que podem causar a morte, como as cêrcas eletrificadas, levando a pensar: - se os colocarmos para defender meramente a propriedade material, que aconteceria, se ao funcionar, ocasionassem a morte do atacante?

Em verdade os aparelhos de defesa dos nossos bens materiais são legítimos se atuam, como podia fazer o proprietário, caso estivesse presente. Assim reduzimos as questões dos modernos "ofendícula", porém, nos fica o problema intato - o de se teremos direito a repelir a agressão contra a propriedade em forma tão brutal que ocasione a morte do atacante. $\mathrm{O}$ assunto há de ser resolvido de acôrdo com a necessidade da defesa, de que falarei quando expuser os requisitos.

\section{5 - REQUISITOS}

Quais são êles?

Todos os enumerados no artigo 21 do Código Penal Brasileiro. A agressão é o primeiro, tanto sob o ponto de vista cronológico, como do prius lógico da legítima defesa. Deve haver agressão Não se pode falar de legítima defesa sem agressão, logo, o que se impõe, em primeiro lugar, é a agressão.

Mas como deve ser ela?

Diz a lei: - injusta.

Não faltou quem dissesse que, relativamente à agressão, não se precisa usar do adjetivo injusta, porque não há nenhuma que não o seja. A expressão agressão, que supõe um ato de ataque, não necessitava do vocábulo injusta. Mas, em verdade, pode e deve tomarse em um sentido material de ato e por isso é necessário que se diga - agressão injusta.

A defesa putativa supõe uma agressão, para o que crê que vai ser agredido, e, se não se falasse em agressão injusta, a defesa putativa podia considerar-se como legítima defesa, o que não é exato.

A injustiça deve ser material. Desde o direito romano se fala que agressão injusta deve ser tambémt atual. Quando falava CARRARA da natureza da legítima defesa, dizia que se não fôsse atual a agressão o indivíduo podia e devia pedir amparo à polícia. Assim, quando recebemos uma ameaça, podemos solicitar à polícia que nos preste proteção. Não é possível que nos defendamos de uma agressão futura. Com maior razão não cabe legítima defesa contra uma agressão passada, salvo se estiver na iminência de ser repetida.

Assim, se somos agredidos por uma pessoa armada de faca, e a desarmamos e ela renova ou faz menção de renovar a agressão com um revólver que trazia oculto, colocamo-nos, novamente, em estado de legítima defesa, não contra a agressão passada mas contra a atual, ou iminente.

Convém frisar, - passada a agressão, desaparece a legitimidade da defesa para dar lugar à vingança. Cabe também legítima defesa contra uma agressão futura desde que seja iminente.

As Partidas do século XIII, já afirmavam o direito de repelir uma agressão iminente. $\mathrm{E}$ as razões que davam eram de grande segurança. Diziam: - o agredido não deve esperar ser acometido porque podia morrer e já não se podia amparar. Há, porém, o caso de alguns códitros, como o espanhol que não se refere à agressão iminente, reconhecida, entretanto, em face do trabalho dos dogmáticos e da jurisprudência.

Os problemas de maior transcedência são os que se referem à necessidade da defesa. A definicão do Código Penal Brasileiro nos 
mostra que um dos requisitos está no texto - meios necessários. Sem saber porque, a exposição de motivos referiu a necessidade da proporção.

Recordemos que na Alemanha o que chamamos de legítima defesa se chama defesa necessária (Notrecht), que nasce junto ao estado necessário e que pertence a um direito de necessidade, que pode provir da agressão ou do conflito de bens. Na Alemanha se disse que a necessidade é circunstancial, isto é, quando é necessária do ponto de vista de sua qualidade, da sua iminência, quer dizer uma necessidade não material, senão quanto à eventualidade do ato.

Se um homem está deitado, vítima de um acidente, todo engessado, com exceção do braço direito, vê entrar uma criança que Ihe quer roubar umas salsichas, como não há outro meio para evitar a subtração senão disparar o revólver, que tem à cabeceira, ao alcance de sua mão válida, pode matar a criança; entretanto, se fôra um cahorro, não poderia matá-lo porque não cabe legítima defesa contra um animal, e o homem deitado e inválido estaria, quanto ao cão, em estado de necessidade; e, para que êste estado de necessidade seja possível, se necessita que o bem que se sacrifica seja inferior ao que se salva, e o cão é superior às salsichas. Felizmente essa interpretação, tão torpe como injusta, não impera hoje. Em vez de interpretar a necessidade com respeito às circunstâncias há que fazêtlo em relação ao direito que se defende.

A lei diz meios necessários. Para defender a propriedade não se necessita agredir a pessoa do ladrão com o fim de dar-lhe morte. Os meios nesse caso não seriam necessários.

Quando falarmos da proporcionalidade veremos que interpretação mais curiosa deu a exposição de motivos ao texto. A primeira condição é que seja necessária porque não pode haver legítima defesa sem agressão e sem necessidade. Logo, aquele que emprega meio não necessário não pode falar em legitíma defesa. Já que vimos êsses dois requisitos vamos analisar êsse outro que o Código Brasileiro. diz - usando moderadamente dos meios. Aqui se trata de proporção. Já falei que em Roma se dizia arma armis e em Direito Canônico "MODERAMEN INCULPATE TUELAE". A moderação não quer dizer que a proporção seja absoluta, deve ser racional aos meios que se emprega. Em nenhuma parte do texto do artigo 21 se fala de proporcionalidade racional, mas o Código tem uma exposição de motivos que diz: O QUE SE EXIGE É APENAS A MODERAÇÃO DO REVIDE, O EXERCICIO DA DEFESA NO LIMITE RA. ZOÁVEL DA NECESSIDADE". Mas, de onde tira a exposição de motivos que a proporcionalidade racionalizada há de deduzir-se da necessidade? Quando a lei diz "USANDO MODERADAMENTE DOS MEIOS NECESSÁRIOS”, a necessidade não indica a raciona- lidade da proporção mas a imprescindibilidade mesma dos meios. Ao lado dêsses requisitos caberia falar de outro que não aparece no Código - a ausência de provocação. O texto não fala dêsse requisito. Fala apenas em moderação e em emprêgo de meios necessários. Se ño há moderacão, há excesso. No parágrafo único do artigo 21 há algo mais interessante porque se vale dos limites da legítima defesa que não são apenas os mieios mas todos os elementos. Poder-se-ia falar da existência de provocação ou excesso na causa para constituir uma forma mais ampla de defesa excessiva?" Se nós outros em uma jogada de cartas proferimos contra nosso parceiro, expressões injuriosas e o mesmo saca de uma arma e nos quer matar, estamos ou não em legítima defesa, se de nossa parte repelimos a agressão à mão armada? O problema é muito grave e o abordaremos no final.

\section{6 - ÂNIMO DE ATAQUE E DE DEFESA}

Antes de tratarmos da falta de provocação e do excesso há duas outras questões importantes - o ânimo de ataque e o ânimo de defesa. Cabe invocar o elemento subjetivo do injusto em relação à legítima defesa na agressão ou no ataque. No ânimo de ataque, por exemplo, se desejando assustar um amigo pusilânime o ameaço com uma arma descarregada (circunstância por êle ignorada) e êle repele a suposta agressão, há legítima defesa? Não, porque as causas de justificação são objetivas. Por isso a objetividade se reforça aqui com um elemento subjetivo - o ânimo de ataque. O ânimo de defesa consiste em que o indivíduo que se defende tenha efetivamnte o ânimo de defender-se. E' curioso que o Código Espanhol quando fala da legítima defesa de terceiro diz que ela não se legitima quando o agente procede com o fim de vingança ou outro motivo ilícito, o que quer dizer que exige o ânimo de defesa. Há quem deseje que o elemento subjetivo do injusto seja invocado na legítima defesa mas reconhece que o pretexto da legítima defesa não é legítima defesa. $O$ pretexto da legítima defesa foi invocado primeiramente por BIN DING. Suponhamos dois companheiros, um dos quais tem oculto desejo de vingança do outro, que, apesar de bondoso, é fàcilmente irritável, principalmente quando bebe. Sabedor disso, o que deseja vingar-se, dá ao outro um copo de aguardente e depois o injuria levemente, logrando exasperá-lo. Exasperado saca de uma arma contra o primeiro e, êste aproveitando a circunstância da agressão, o mata. Poderia dizer-se que o matador está em legítima defesa? Responde BINDING que, no caso, há apenas, o pretexto de defesa por faltar ânimo de defesa, pois tudo quanto fêz o agente foi para vingar-se, criar uma situação favorável a fím de matar impunemente o companheiro. 


\section{7 - A FALTA DE PROVOCAÇÃO E O EXCESSO}

O parágrafo único do artigo 21 diz: - "O AGENTE QUE EXCEDE CULPOSAMENTE OS LIMITES DA LEGITTIMA DEFESA, RESPONDE PELO FATO, SE ESSE É PUNÍVEL COMO CRIME CULPOSO". Vemos que aqui se fala dos limites, não apenas dos meios. Por que, então se referiu o texto apenas ao excesso culposo? JÁ IMPALLOMENI dizia que muitas vêzes o excesso da defesa podia vir do dolo. O indivíduo que se excede o faz intencionalmente para precaver-se melhor da agressão que pode ser maior do que parece. $\mathrm{O}$ homem que agredido a bofetadas, à noite, temendo uma agressão mais grave, mata o agressor não porque tenha mêdo, senão porque quis precaver-se de um maior perigo ainda inexistente, está em defesa excessiva ou se anula todo o estado de defesa? ALIMENA, no exemplo do indivíduo que originou a agressão de umas leves injúrias, diz: - "castigue-se-o pelas injúrias mas não se lhe negue, o direito de defesa por não se deixar matar impunemente".

Se nos referimos ao parágrafo único do atrigo 21 não só devemos tratar do excesso nos meios, senão também do chamado excesso na causa; quer dizer 'do caso em que precedeu provocação, ainda oue não suficiente por parte do que ataca e que logo resulta agredido pelo que quer defender-se. Não haveria dificuldade em admitir que o excesso na causa configura também a defesa excessiva porque o parágrafo único do art. 21 , fala dos limites em geral e não dos meios. Mas o obstáculo está em que o aludido texto impõe a condição de que o agente se excede culposamente. Mas o que o Código diz é que o excesso culposo se castiga como delito por culpa. O que ocorrerá se o excesso na causa em vez de ser por dolo fôr.por culpa? A exposição de motivos diz "corolário", "a contrário sensu": se o excesso é conscientemente querido, responde o agente por crime doloso, pouco importando o estado inicial da lesítima defesa".

Em nosso juízo a exposição de motivos se equivoca. O artigo 21 exige a moderação, o parágrafo único resolve o caso por excesso dizendo-o culposo. A lei não diz nada pelo excesso por dolo e a justa interpretação seria conforme o artigo 21 , e não o parágrafo único, considerar que, também no caso de excesso por dolo, fôra o expresso no meio, e na causa havia uma defesa excessiva. Seria aqui aplicável o que disse ALIMENA - quando se tratar de excesso na causa: "castigar os atos de provocação mas não punir como homicida ao que não se deixa matar por obstáculo. Para nossa interpretação não o é em verdade. A exposição de motivos não é o texto da lei, indica sua origem, ou é, se o quiserem, a vontade do legislador, mas na interpretação não se fala dessa vontade e sim da vontade da lei, que não é a do legislador, porque a lei tem a sua vontade través dos tempos, e se descobre pela interpretação progressiva. A o e legislador, que é o pa exposiçá de motivos diz o quejam uma coisa a sai outra. Como da lei, mas às vêzes os pais desejam nao inotarta que o autor diga vimos, a necessidade é dos meios, náo importa que õ̃o porque a que a necessidade se refere à racionalidade na proporção porque na lei diz outra coisa, como já demonstramos. Do me tem valor algum que a exposição de motivos aftrme que o excesso

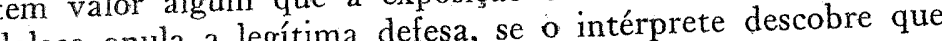
doloso anula a legitima defesa, se o ine alegar-se que a exposição de tade da lei é outra. Tampouco pode alegar-se quão desta classe é motivos seja interpretação autêntica. Interpretação desta cláse é a que legislador, não o codificador, em uma nova lei, se uma a que faz o legislar, na e costerior, ou no próprio articulado do cóinterpretação autêntica e posterior, ou e contextual.

digo, se é uma interpretação autênica e con extua da lei, nem sua

Em suma, a exposição de motivos não é o texto da lei, nem suainterpretação autêntica, e só indica a vontade do vontade da lei só a le como gênesis das disposições legais; mas a vontade da lei gramale como genesinérprete judicial pelos meios interpretativos, gramaticais e teleológicos.

\section{RELATÓRIO E PARECER}

\section{Relator: LUIZ LOPES PALMEIRO}

Houve sempre entre os estudiosos do Direito Penal e Jiménez Houve sempre entréácl corrente de simpatia, nascida do estide Asúa uma inquebrantavel corrente de simpasinamentos sem doglo elegante e fácil de sua obra escrita, de seus ensinamento opulento. matismos nem presunções, da claridade de seu pensamento opulence

$\hat{E}$ mestre. E o é sem intransigências, pois sabe que a ciência dinâmica ou, como afirmou Carrara, que a ciência é tão só un problemas que o grama "contestá chamado a estudar".

Heste Congresso Jurídico, com magnífica valiosa contribuicão. E aqui está, brilhante e erudito, transido de e valiosa contribua. sinceridade e de ciência, espondo, sem alardes, su eno no digo Penal Brileiro. sôbre a legítina defesa na doutrina e no Código Penal Brasile supõe

Em matéria penal, uma instituição não é sempre o qù sêzos, - legislador que a traduz em palavras. Tem antecedentes, às lograr remotos, e consequiências, às vêzes, muito graves. Procura-se lograr ım propósito e não se alcança; abandona-se outro e se o impõe sem saber nem querer. Daí a complexidade da obra de

cador penal. Sabe o que aspira, mas não o que consegue. As concepções teóricas não se confundem com
práticas, e, por vêzes, delas diferem. Quando, escreve Juan P. Ra- 
mos, quando o critério filosófico de orientação se manifesta na órbita puramente mental das idéias, a concepç̃o resulta às vêzes, or uma coerência admirável concepção resulta, as vêzes, de na, que durante quarent, como o demonstra a escola positiva italiapugnações de seus adverśácios, venceu, na doutrina, a tôdas as imseu sistema du era a essencia íntima de da social derivada da temibilidade do delinqüente; mas, quando êsse critério filosófico espira a concretizar-se em um código, aparecem critério fllosótões insolúveis derivadas da complexidade de fatôres graves quesnam a ação de um delinqüente, que pode de fatôres que determido crime, e que vive não sente, que não reage que não sociedade que não pensa, que castiga, que não previne com de Direito Penal.

Disso derivam o colorido e a forma do trabalho de Jiménez de Asúa. Ao invés de estudar o código na base do que autores na exposiç̃o de disseram seus cado pelos juízes de acôrdo como ao invés de supor que ia ser apliaparente, os seus artigos, com o que expressam, de u'a maneira aparente, os seus artigos, ao invés de analisá-lo minuciosamente, para estabelecer sua concordância, mais ou menos visível, com outros. códigos, foi êle buscar a raiz de seu pensamento inspirador central pa ra forjar, assim, soluçóes possíveis para complexos problemas no Direito Penal, que está profundamente vinculado com a vida e com a

$\mathrm{O}$ eminente profess

trabalho conceituando Jiménez de Asúa começa o seu esplêndido pulsa necessári à a legítima defesa. Assim a define: “ $E$ ' a re fender nosso dirto iminente, para dede outrém, sempre que houver a proporção os meios e não houver provocação por parte de quem se defende".

Assinala que esta definição não é a mesma adotada pelo Código Penal Brasileiro em seu artigo 21 elo Códidiscorrer sôbre a legítima defesa 21 , e passa, de forma rápida, a tão, que na Idade Média, durante tôdés dos tempos. Salienta, enma dorante tôda a Idade Média, foi a leóítie nas Partidas, no século XIII mesma forma atual.

No século XVIII, a legítima defesa passou a figurar na parte geral, onde continua, não obstante aparecer, ao contrário, no Código Napoleônico, encravada na parte especial junto ao homicídio.

A seguir, entra o autor a estudar a natureza jurídica da legítima defesa.

Cita Puffendorf. Julga, porém, sua teoria não só insuficiente como. equívoca, pois não é possível, diz o autor, conceber a legítima defesa como impulsionada pela perturbação, porque, nesse caso, seria causa de inimputabilidade e não de justificação.

Parece-nos oportuno, nesse passo, referir ràpidamente as teodamentos. Vamos dividí-las em três grupos gerais, afim de sermos - mais suscinto possível.

No primeiro grupo, colocamos as teorias da simples impunidade da legítima defesa, isto é, aquelas que conisderam o ato praticado em legítima defesa como simplesmente impune, sem entrar em quaisquer considerações de ordem jurídica. Pertencem a êste grupo:

a) Teoria da coação psíquica, de Puffendorf.

Nesas teoria sustenta-se que o indivíduo que se defende sob a ameaça de uma agressão injusta e iminente, sofre uma espécie de coacão psíquica que lhe elimina a faculdade de escolha, suprimindo-ihe o querer e o impelindo ao sacrifício do direito do agressor. Não havendo liberdade de querer, eliminada a faculdade de escolha, tornase inexistente o elemento subjetivo do crime, que é essencial à configuração delituosa.

Carrara, expondo e criticando essa teoria, mostra como é falho o conceito de coação psíquica frente ao scasos concretos e, sobretudo, quando se refere ao fato de a legítima defesa ser lìcitamente praticada em favor de terceiro, que é, como diz Jiménez de Asúa, a sua mais elegante forma.

Maggiore, Impallomeni, Penso e Ferri manifestam-se também contrários a esta doutrina. Por outro lado, Rossi, Pastore, Vidal, Chevau et Helie, Carmignani e Pessina defendem-na.

b) Teoria da inutilidade da ameaça penal, exposta e defendida por Kant.

Kant parte da afirmativa de que uma das funções primordiais da lei penal é a intimidação, isto é, a norma penal, intimidando com a sanção, visa criar regras externas de conduta, pelas quais norteie o indivíduo seu comportamento social. No caso da legítima defesa, a ameaça penal torna-se inteiramente irrelevante e inútil. Conseqüentemente, a capacidade de livre escolha do indivíduo fica eliminada ante a agressão injusta e inesperada e a função intimidativa da norma penal deixa de se fazer sentir, frente a essas especiais circunstancias.

c) Teoria da colisão de direitos, exposta e defendida por Von Buri.

A legítima defesa, diz êsse autor, não é punível porque há um choque entre direitos, e esta colisão faz com que o agressor injusto perca a proteção legal do seu próprio direito, havendo como que uma renúncia por parte do atacante e em referência ao seu próprio direito, a favor do agredido injustamente. Não sendo possível, no caso, a conservação dos direitos de um sem a conseqüente destrui- 
ৎ̧ão dos direitos do outro, o Estado deve proteger o direito mais importante, que é, justamente, o do agredido, direito superior e ao qual se deve submeter o do atacante.

No segundo grupo, colocamos as teorias de justificativa, isto é ,aquelas que consideram o ato cometido em legítima defesa como sendo perfeitamente lícito.

Pertencem a êste conjunto:

a) Teoria do direito de necessidade, exposta e defendida por Hegel.

A legítima defesa, diz Hegel, é um ato que constitui verdadeiro exercício de um direito, qual seja o direito de necessidade. O fato da legítima defesa e uma conseqüência das circunstâncias, e quem quer que se encontre em tal situação sente-se na contingência de sacrificar o próprio direito ou destruir o alheio. Se o crime é a negação do direito, a defesa é, portanto, a sua afirmação.

b) Teoria da cessação do direito de punir, defendida por Carrara. A natureza, diz o insigne mestre, impóe ao indivíduo o direito de defender seus próprios direitos e a lei jurídica, humana, que não poderia ir contra esta lei natural, tem de reconhecer o direito de legítima defesa ao indivíduo, cessando o direito punitivo do Estado. Portanto, o fundamento da legítima defesa reside na impossibilidade momentânea que atravessa o Estado de evitar a agressão e proteger a vítima, sendo assim justo e lícito que esta mesma se defenda. A defesa privada constitui, dessa forma, um substitutivo à defesa pública.

A instituição da legítima defesa representa, em suma, uma delegação hipotética e condicional do poder de polícia que o Estado faz ao indivíduo em razão de necessidade, quando reconhece não poder prestar oportuna e eficazmente, a êle ou a outros, sua proteção (Manzini).

São favoráveis a essa teoria Garraud, Fuerbach, Tarde, Ortolan Cuello Calón. Contra ela alinham-se Florian, Penso e Sivoli.

c) Teoria da completa licitude do ato, de Jhering.

$O$ indivíduo, diz o autor, em estado de legítima defesa, deve ser equiparado ao que exercita um direito. Valendo-se do direito de defesa que a lei lhe assegura, não pode ter sua atividade considerada como criminosa. Quem usa do direito de defesa não lesa nenhum outro direito, age licitamente. Binding é adepto dessa teoria.

No terceiro e último grupo de teorias, colocamos os positivistas.

a) Teoria da justificação positiva, defendida pelo grande Ferri. Expõe Ferri: Se por critério da imputabilidade criminal adotarmos o da juridicade ou antijuricidade dos motivos, resulta claramente que quem age em legítima defesa é movido por motivo jurídico.
Em súmula, o pensamento desenvolvido pela escola positiva é que a agressão injusta está a revelar a temibilidade do agente, sua periculosidade social. Quem repulsa o atacante pratica, pois, um ato de justiça social.

O exercício da legítima defesa, diz Fioretti, representa, portanto, uma função eminentemente social, em cujo cumprimento não sabe dizer quem tem maior interêsse, se a sociedade, $s$ o indivíduo agredido nos seus direitos. Ela está, por isso, bem longe de representar um direito puramente individual, monástico, como pretende Vico. $\hat{E}$ um direito, quer no sentido objetivo, quer no subjetivo. $\hat{E}$ um direito no sentido objetivo porque, é uma norma que representa uma condição necessária à existência da sociedade humana. E é de direito no sentido subjetivo porque outro nome não se poderia dar à faculdade que tem tôda pessoa de agir conformemente ao interêsse: social e ao próprio.

Concluindo, opina o mesmo autor serem o interêsse da conservação da integridade pessoal do indivíduo honesto e o interêsse de repressão ou eliminação da atividade criminosa que se manifesta na injustiça da agressão, os capitéis do edifício da legítima defesa. Sôbre êstes sustentáculos se ergue o instituto.

Florian é partidário desta doutrina. Solér faz-lhe a crítica.

b) Teoria da periculosidade do agente, exposta e defendida por Zerboglio.

O agressor, diz êste autor, representa o indivíduo perigoso e nocivo à sociedade, enquanto que o agredido não representa nenhuma periculosidade ao defender-se do ataque injusto, de onde resulta. não merecer punição.

Tôdas estas teorias, mais ou menos engenhosas, oferecem largo. flanco aos ataques da crítica.

Jiménez de Asúa, depois de refutar a teoria sustentada por Puffendorf, e indagando se haveria uma falta de dolo na legítima defesa, toma posição ao admitir que, agindo em legítima defesa, se esta é em verdade legítima, o agente realiza uma causa de justificação, se legitima intrìnsecamente o fato. A causa de justificação faz desaparecer uma injustiça aparente e deixa claro que a conduta de quem se defende é legítima.

Daí surgem várias conseqüências. Os positivistas, especialmente Fioretti, Zerboglio, Florian e Ferri, sustentam que a legítima defesa é uma justificação subjetiva, aplicando a tese de falta de reação do homem com fim anti-social, ou seja, a teoria dos motivos anti-sociais e sociais.

Começa, nessa altura, o trabalho do professor Jiménez de Asúa a ganhar profundidade e originalidade. Insiste que a legítima defesa não provém dos motivos, mas das justificações objetivas. A índole 
objetiva do injurto, observa com propriedade e agudeza, faz com que seja objetiva a injustiça, e que, se a justifica, não é porque assim creia subjetivamente o agente, mas por não ser anti-social o motivo, visto estar conforme à norma de cultura.

Um louco pratica atos, continua Jiménez de Asúa, pelos quais não é responsável, mas contra êle cabe a legítima defesa, porque, objetivamente, a conduta do louco é injusta. Contràriamente, não cabe legítima defesa contra os animais, por serem incapazes de atos injustos. Se matarmos um cachorro que nos quer morder, há um estado de necessidade, pois a legítima defesa só pode resultar de um ato injusto privativo de um ser humano.

Com relação ao primeiro caso, acrescentamos nós que o mesmo ocorre se a agressão parte de um menor, de um inimputável, pois es ta, igualmente, não poderá ser admitida como subjetivamente injusta. Objetivamente, entretanto, o fato surje injusto, para aquêle que o sofre. Existe legítima defesa, quer o agente, aquêle que invoca essa justificativa, se defenda da ação de um homem normal, quer reaja aos impulsos perigosos de um alienado ou de um menor.

Jiménez de Asúa discorda de Ferri no tocante à legítima defesa recíproca. Entende que esta é impossível. Cita o exemplo do homem que, em sua própria casa, surpreende o noivo da cozinheira, que faz um movimento que supõe ser agressivo, e, diante disso, dispara o seu revólver e recebe, em revide, um trio mortal. Nega, a esta hipótese formulada por Ferri, que ocorra legítima defesa recíproca, entendendo que, nesse caso, o dono da casa se encontraya em tado de defesa putativa, vistọ como a legítima defesa real é essencialmente objetiva. O noivo da cozinheira, sem agredir, foi agredido. Logo, agiu em legítima defesa. O proprietário da pondo-se na iminência de uma agressão, agiu por êrro, portanto, em defesa putativa.

$\mathrm{O}$ artigo 17 do Código Penal Brasileiro reza: " $\mathrm{E}$ ' isento de pena quem comete o crime por êrro quanto ao fato que o constitui, ou quem, por êrro plenamente justificado pelas circunstâncias, supõe situação de fato que, se existisse, tornaria a ação legítima".

Essa disposição, ensina Basileu Garcia, ilustre professor de Direito Penal na Faculdade de Direito da Universidade de São Paulo, torna evidente que aquêle que não se encontra em situação real de legítima defesa, mas supõe encontrar-se, por êrro, desde que a suposição seja razoável, pode ter em seu favor essa causa de exclusão da criminalidade. Assim, a hipótese de alguém que mate o antagonista que lhe aponta um revólver descarregado. Não tem motivos o agente para imaginar que a arma está descarregada. Subjetivamente, acha-se em legítima defesa, de modo que, se praticar a repulsa nessas condições, se encontrará putativamente em legítima defesa. Ocorre, portanto, essa causa de exclusão da criminalidade sem seu benefício.

E a legítima defesa recíproca? E' admissível? E' possível duas pessoas se encontrarem, reciprocamente, em legítima defesa?

Parece-nos que não, porque a legítima defesa pressupõe uma agressão injusta. Se alguém está em legítima defesa, é porque o seu antagonista se acha em situação injusta e, por isso, êste não pode invocar a legítima defesa.

E' possível porém, a legítima defesa recíproca, em virtude de se admitir a legítima defesa putativa. Suponhamos a hipótese, apresentada pelo professor Basileu Garcia, de dois policiais à procura de um criminoso num compartimento quase todo escuro, em grave equívoco um em relação ao outro. Um dêles percebe um vulto que lhe vai atirar e, ao mesmo tempo, saca de sua arma e atira no imaginário antagonista, que é o seu colega. Temos, nesse caso, os dois homens em legítima defesa recíproca, quando ambos os autores do fato, ou algum dêles, estão em legítima defesa putativa.

Jiménez de Asúa, para corroborar a sua afirmativa de que a legítima defesa recíproca não é possível, porque quem pratica um ato injusto não pode estar em legítima defesa, traz um exemplo interessante e que merece ser repetido. Ei-lo. Vai ser executado um condenado à morte. $O$ verdugo vai realizar a execução do prêso, que não se pode opor, porque não cabe legítima defesa contra um ato lícito.

Dessas conseqüências deduz que a legítima defesa é considerada, em seu verdadeiro sentido, como causa de justificação.

Passa o autor do brilhante trabalho ora relatado, no capítulo "Direitos que Protege", à interpretação técnico-dogmática da legítima defesa, determinando os bens jurídicos que podem ser alvo de ofensa e que devem ser, portanto, objeto de defesa.

O Código Penal Brasileiro, artigo 21 não faz discriminação dos bens, mas numa forma genérica, alude a direito seu ou de outrem, sem dizer que espécies de direitos são êsses.

Há portanto dois titulares de defesa; e está claro que a justificativa é cabível, não só à defesa própria, como de terceiros, podendo se esta exercida tanto pelo parente, como por pessoa estranha. Isso está expresso no texto do artigo aludido. Quanto às espécies de interêsses jurídicos que possam ser defendidos legitimamente, embora não estejam enunciados ou limitados expressamente, conclui o autor que todos os bens ou interêsses jurídicos (a vida, a integridade corporal, a honra, a propriedade, a liberdade) são protegidos através dessa justificativa, e acrescentamos nós, desde que suscetíveis de agressão material.

A honra poderá também ser objeto da legítima defesa? Uma vez que não existe restrição no texto legal achamos que sim. Mas que espécie de honra? Porque a honra é expressão que comporta diversas 
idéias. A honra objeto do crime de difamação ou injúria, poderá ser protegida pela legítima defesa?

Nossa opinião é que não cabe a legítima defesa, e isso porque os atos de repulsa de uma pessoa que sofre ofensa à sua dignidade assumem uma feição não consentânea com os requisitos da legítima defesa.

Encaremos duas hipóteses. A pessoa ofendida na sua reputação, repelindo a ofensa por meio de atos análogos, isto é, ofendendo também a pessoa que a ofendeu, ou tomando um desfôrço pessoal. Se repelir a ofensa por meio de palavras, o caso está compreendido nas disposições legais que fazem compensar-se as injúrias e essa espécie de repulsa não incidirá no âmbito jurídico da legítima defesa. Se reagir pelo emprêgo da fôrça, não estará evitando a consumação de uma agressão, mas apenas vingando-se. Isso não constitui legítima defesa.

Mas a honra no sentido de pudicícia ou pudor, esta, sim, pode ser objeto de legítima defesa. Suponhamos uma mulher assaltada por alguém que lhe quer macular a honra, atentando contra o seu pudor. Ela tem o direito de até mátar, se necessário, o ofensor, em legítima defesa de sua honra:

Cremos que em face do nosso Código Penal só os direitos suscetíveis de agressão material podem ser protegidos pela legítima defesa. Exigem-se uma agressão atual e injusta e o emprêgo de meios necessários para repelir essa agressão; deve existir moderação na repulsa. Tudo isso depõe no sentido de só se admitir a repulsa a agressões materiais (Basileu Garcia).

Jiménez de Asúa confessa, ainda no capítulo mencionado, que não é de fácil solução o caso em que uma pessoa trata de defender sua propriedade ou a de outrem. Promete abordar êsse assunto, como se verá no capítulo seguinte de seu trabalho.

Passa assim ao estudo dos pressupostos da legítima defesa.

Diz êle que deve haver agressão. E deve ser o primeiro requisito, tanto sob o ponto de vista cronológico, como do prius lógico da legítima defesa. Não se pode falar de legítima defesa sem agressão. Logo, o que se impõe, em primeiro lugar, é a agressão.

Há quem diga que, relativamente à agressão não se precisa usar do adjetivo injusta, porque se inclui implicitamente na agressão a noção de ausência de provocação. O professor Jiménez de Asúa entretanto sustenta que a expressão agressão deve ser tomada em um sentido material de ato e por isso é necessário que se diga agressão injusta.

A defesa putativa supõe uma agressão, para o que crê que vai ser agredido, e, senão se falassem em agressão injusta, a defesa putativa podia ser admitida como legítima defesa, o que não é exato.
Sustenta ainda que a injustiça deve ser material. Lembra que desde o Direito Romano se fala que a agressão injusta deve ser também atual, e frisa que passada a agressão desaparece a legitimidade da defesa para dar lugar à vingança, cabendo, porém, legítima defesa contra uma agressão futura desde que seja eminente.

Salienta, por entender transcendentes, os problemas que se referem à necessidade da defsa.

Diz o Código Brasileiro - meios necessários. À idéia de necessidade está ligada a idéia de moderação. Para que alguém proceda moderadamente, é preciso que não ultrapasse aquilo que é necessário. Desde que se exceda, deixa de agir moderadamente. As palavras moderadamente e necessário estão, a nosso ver, substituindo os requisitos do Código de 1890, impossibilidade de prevenir ou obstar ação e de invocar e receber socorro da autoridade pública e emprêgo de meios adequados para evitar o mal em proporção da agressã̃.

Exposta essa nossa opinião voltemos ao trabalho de Asúa. Diz êle que um dos requisitos - meios necessários - está no texto na definição do Código Penal Brasileiro.

Recorda que na Alemanha, o que chamamos de legítima defesa se chama defesa necessária. Na Alemanha se diz que a necessidade é circunstancial, isto é, quando é necessária do ponto de vista de sua qualidade, da sua iminência, quer dizer uma necessidade não material, senão quanto à eventualidade do ato.

A necessidade porém em vez de ser interpretada com respeito às circunstâncias, deve ser feita em relação ao direito que se defende.

A lei diz meios necessários. Para defender a propriedade não se necessita agredir a pessoa do ladrão com o fim de dar-lhe morte. Os meios nesse caso não seriam necessários.

A seguir aborda o requisito - usando moderadamente dos meios. Diz que a moderação não quer dizer que a proporção, pois, segundo êle, na moderação se trata da proporção, seja absoluta, deve ser racional aos meios que se empregam.

Não encontra no texto do artigo 21 a proporcionalidade racional.

Estranha que na exposição de motivos se pretenda que a proporcionalidade racionalizada venha a se deduzir da necessidade. Quando a lei diz usando moderadamento dos meios necessários, a necessidade não indica racionalidade da proporção mas a imprescindibilidade mesmo dos meios.

Ao lado dos requisitos enunciados, julga o ilustre autor, que caberia o da ausência de provocação. $O$ texto não fala dêsse requisito. Fala apenas em moderação e emprêgo de meios necessários.

No capítulo "Ânimo de Ataque e de Defesa", Jiménez de Asúa invoca o elemento subjetivo do injusto em relação à legítima defesa na agressão ou no ataque. 
No ânimo de ataque, por exemplo, se desejando assustar um amigo pusilânime o ameaço com uma arma descarregada (circunstância por êle ignorada) e êle repéle a suposta agressão, pergunta-se, há legítima defesa? Jimeniz de Asúa responde não, porque as causas de justificação são objetivas e reforçadas com um elemento subjetivo - o ânimo de ataque.

$\mathrm{O}$ ânimo de defesa consiste em que o indivíduo que se defende tenha efetivamente êsse ânimo, o ânimo de defender-se. Há quem deseje que o elemento subjetivo do injusto seja invocado na legítima defesa.

Finalmente passa o autor a fazer considerações sôbre o parágrafo único do artigo 21 do Código Penal Brasileiro.

Êste artigo preceitua: "O agente que excede culposamente os limites da legítima defesa responde pelo fato, se êste é punível como crime culposo"

Sabemos que a moderação é requisito de legítima defesa. O agente não deve exceder-se nos meios empregados, mas utilizar-se dos meios necessários, tão-sòmente. Quando, porém, a pessoa que ofende um bem jurídico importante, suponhamos a vida, encontra-se em situação angustiosa, por fôrça de graves e sérias dificuldades, não se pode exigir que, nessa situação, proceda com cuidados dosados. Deve-se admitir, como tolerância, algum excesso, que seja, conforme a hipótese, escusado. Pode acontecer que o excesso tenha sido intencional, doloso. A pessoa estava de início em legítima defesa; a agressão que sofreu era atual e injusta. Utilizou-se de meios necessários à repulsa, mas tomou-se de ódio pelo agressor e excedeu-se voluntàriamente. Nesse caso não se falaria em legítima defesa.

Pode dar-se, porém, que o excesso não seja intencional, resultando do estado de perturbação de ânimo do agente, do mêdo de sucumbir. Então, falar-se-á em excesso culposo e não em excesso doloso e o agente deve ser punido por não haver procedido com moderação. A pena ser-lhe-á imposta com brandura.

No conceito de culpa, há uma atitude inicial lícita do agente. Nos atos praticados em legítima defesa, há também uma atitude lícita do agente. Não tem êle a intenção de ofender, mas de defenderse. Dado êsse pressuposto da origem lícita dos atos praticados, pode dizer-se que o excesso, quando não seja imputável à intenção do agente, poderá sê-lo a sua culpa, stricto sensu.

Para que seja alguém punido por culpa, é preciso que haja na lei previsão explícita da hipótese. O homicídio culposo tem definição legal. Encontramos no Código Penal disposição referente ao homiḉdio culposo. Portanto, alguém que mata, por excesso culposo, o seu antagonista, não tem a justificativa da legítima defesa, mas responde por homicídio culposo. Essa tem sido a inteligência dada ao preceito legal que estamos comentando.

O professor Jiménez de Asúa tece comentários interessantíssimos a respeito da falta de provocação e o excesso na defesa.

Diz que no parágrafo único do citado artigo se fala dos limites e não apenas dos meios. Pergunta por que então se referiu o texto apenas ao excesso culposo. Cita Impalomene e Alimena, para concluir que em face do parágrafo único do artigo 21 não só deve se tratar do excesso dos meios, senão também do chamado excesso na causa. Diz que não haveria dificuldade em admitir-se que o excesso na causa configura também a defesa excessiva porque o parágrafo único do artigo 21 fala dos limites em geral e não dos meios. Mas o obstáculo está em que o aludido texto impõe a condição de que o agente se exceda culposamente e por êsse excesso deve ser punido.

A exposição de motivos diz que quando o excesso é concientemente querido, responde o agente por crime doloso, pouco importando o estado inicial da legítima defesa.

Jiménez de Asúa discorda francamente da exposição de motivos. Acha que a exposição de motivos se equivoca. "O artigo 21 exige a moderação e o $§$ único resolve o caso por excesso dizendo-o culposo. A lei não diz nada pelo excesso por dolo e a justa interpretação seria conforme o artigo 21, e não o $\$$ único, considerar que também no caso de excesso por dolo fôra o excesso no meio; na causa havia uma defesa excessiva. Seria aqui aplicável o que disse Alimena, quando se tratar de excesso na causa: castigar os atos de provocação mas não punir como homicida ao que não se deixa matar por obstáculo. Para nossa interpretação não o é em verdade. A exposição de motivos não é o texto da lei, indica sua origem, ou é, se o quiserem, a vontade do legislador, mas na interpretação não se fala dessa vontade e sim da vontade da lei, que não é a do legislador, porque a lei tem a sua, vontade através dos tempos, e se descobre pela interpretação progressiva. A exposição de motivos diz o que pretende o legislador, que é o pai da lei, mas às vêzes os pais desejam uma coisa e sai outra. Como vimos, a necessidade é dos meios, não importa que o autor diga que a necessidade se refere à racionalidade na proporção porque a lei diz outra coisa, como já demonstramos.

Do mesmo modo não tem valor algum que a exposiç̃o de motivos afirme que o excesso doloso anula a legítima defesa, se o intérprete descobre que a vontade da lei é outra. Tampouco pode alegar-se que a exposição de motivos seja interpretação autêntica. Interpretação desta classe é a que faz o legislador não o codificador, em uma nova lei, se é uma interpretação autêntica e posterior, ou no próprio articulado do código se é uma interpretação autêntica e contextual". 
O professor Jiménez de Asúa conclui o seu brilhante trabalho fazendo, como se vê, uma crítica severa à exposição de motivos, pois esta não é o texto da lei, nem sua interpretação autêntica e só indica a vontade do legislador que vale como gênesis das disposições legais. A vontade da lei só a descobre o intérprete judicial pelos meios interpretativos gramaticais e teleológicos.

Feito, assim, um resumo da contribuição apresentada pelo sábio catedrático espanhol Luiz Jiménez de Asúa ao Congresso Jurídico Nacional comemorativo do cinqüentenário da Faculdade de Direito de Pôrto Alegre, passamos a emitir a respeito a nossa pobre opinião.

\section{P A R E C E R}

Trata-se de um interessante estudo da legítima defesa, feito com clareza e segurança, trazendo sugestões novas e abordando aspectos que merecem nossa meditação.

O trabalho não contém conclusões que devam ser votadas.

Pensamos que o Congresso deve pronunciar-se no sentido de louvar e reconhecer o valor excepcional do trabalho apresentado pelo professor Jiménez de Asúa.

$\mathrm{E}$ ' o nosso parecer.

\section{APRESENTAÇÃO EM PLENÁRIO}

O SR. PRESIDENTE - Júlio César Bonnazzola - Está aberta a sessão. Em discussão a tese "A LEGÍTIMA DEFESA", do professor Jiménez de Asúa, de Espanha, sendo relator o dr. Luiz Lopes Palmeiro, ao qual concedo a palavra. sistas.

O SR. LUIZ PALMEIRO - Sr. Presidente e snrs. Congres-

$$
\text { (Lê a tese) }
$$

O SR. LUIZ PALMEIRO (Após a leitura) - Feito, assim, sr. Presidente, um resumo da contribuição apresentada pelo sábio catedrático espanhol, Jiménez de Asúa, ao Congresso Jurídico Nacional, comemorativo do cinqüentenário da Faculdade de Direito de Pôrto Alegre, passamos a emitir a respeito a nossa pobre opinião.

$$
\text { (Lê o parecer) }
$$

O SR. PRESIDENTE - Estão em consideração as conclusões do dr. Luiz Palmeiro.

Quisera eu dizer algumas palavras. O dr. Luiz Palmeiro, referindo-se às suas conclusões, usou a expressão "minha pobre opinião", com a qual eu não posso concordar. Eu diria, as suas "valiosas conclusões". Pediria, portanto, apenas a supressão da expressão "pobre opinião", empregada pelo eminente relator. (Palmas). Aprovada. (Palmas).

\section{DA NECESSIDADE DE INCLUIR-SE A CADEIRA DE CRIMINOLOGIA NO CURSO DE BACHARELADO}

\section{Napoleão Lyrio Teixeira}

Professor Catedrático de Medicina Legal da Faculdade de Direito da "Universidade do Paraná.

Tomamos a liberdade de enviar a êsse Congresso Jurídico, para debates, o tema que se segue, de interêsse para o ensino do Direito entre nós.

Entremos no assunto: Pelo Conselho Nacional de Educação foi unanimemente aprovada, na sessão de 20 de outubro do ano findo, "Indicação" (posteriormente homologada pelo ministro Mariani), da autoria do prof. Jurandyr Lodi, que fundamentará a presente tese.

Reportou-se o prof. Jurandyr Lodi a oração sua, proferida em sessão inaugural do C. N. E., a 17 de agôsto do mesmo ano, subordinada ao tema - "O ensino jurídico no Brasil" - na qual lembrava a conveniência de efetuar-se consulta às nossas Faculdades de Direito em relação aos defeitos de que, acaso, se ressentisse o curso de bacharelado e "providências a serem tomadas no sentido de os corrigir, aperfeiçoando o desenvolvimento de tais estudos".

Sugeria, a seguir, medidas aconselháveis "a melhorar o nível do ensino de Direito no Brasil, capacitando-o a preencher mais satisfatòriamente suas finalidades específicas" - e destacava as seguintes:

“a) Reduzir a parte teórica dêsse curso, com a supressão das cadeiras de Introducãa à Ciência do Direito (1. ${ }^{\mathrm{a}}$ série), Teoria Geral do Estado (1. ${ }^{\mathrm{a}}$ série) e Direito Internacional Privado ( $5 .^{\text {a }}$ série), deslocando-se para o primeiro ano o estudo do Direito Constitucional;

"b) conjugar-se o ensino da Economia Política (1. série) ao da Ciência das Finanças (2: ${ }^{\mathrm{a}}$ série), ficando aquela como parte introdutóra desta última disciplina, a qual, para melhor conformar-se com o seu conteúdo, se deve denominar Direito Financeiro, abrangendo também o estudo dos princípios e normas do direito tributário; 